\title{
Ciężkie sny na "poduszce pani Marx"1. Ukryta euforia okupacyjnych przewłaszczeń w Polsce
}

Romana Kolarzowa

TEKSTY DRUGIE 2017, NR 2, S. 318-332

DOI: $10.18318 /$ td.2017.2.18

$\dot{\mathbf{s}}$ wiat bez Żydów, a co najmniej Polska bez Żydów stów. Temu marzeniu poświęcano systematyczne publikacje, otwarcie nawiązujące do projektów narodowych socjalistów w Niemczech. O zainteresowaniu realizacją tych projektów i życzliwej ich obserwacji zapewniał (m.in.) Jędrzej Giertych. O tej życzliwości, sprawiającej, że np. lektura okupacyjnej prasy podziemnej, wydawanej przez organizacje nacjonalistyczne, $i$ tzw. prasy gadzinowej nie pozwala, bez znajomości afiliacji tytułów, rozdzielić ich stanowisk w tej kwestii ${ }^{2}$. Obfitość tej literatury, mało

1 Historię poduszki Pani Marx przedstawił Saul Friedlander w książce Czas eksterminacji. Nazistowskie Niemcy i Żydzi 1939-1945, przeł. S. Kupisz, K. Masłowski, A.M. Nowak, Warszawa 2010, cz. I, r. 3. Przywoływał tę historię J.T. Gross w trakcie kilku dyskusji wokół swojej pracy Sq̨siedzi. Historia zagłady żydowskiego miasteczka, Warszawa 2000.

2 D. Libionka "Kwestia żydowska” i problemy własnościowe w ujęciu wydawnictw konspiracyjnych ugrupowań nacjonalistycznych, w: J. Grabowski, D. Libionka (red.) Klucze i kasa. O mieniu żydowskim w Polsce

\section{Romana}

Kolarzowa - dr hab., pracuje w Instytucie Filozofii Uniwersytetu Rzeszowskiego. Zajmuje się antropologią kultury, kulturą żydowską i filozofią dialogu. W szczególności - rolą doświadczeń traumatycznych w procesie samoidentyfikacji i kwestią ich długotrwałego „nieumiejscowienia” w dyskursie humanistycznym, w perspektywie innej niż „dyskurs o ofiarach". 
zresztą przebadanej, pozostaje w rażącej dysproporcji do nikłości refleksji nad spełnieniem tego marzenia. Oficjalne oburzenie zbrodniami wojennymi i zachowywanie formalnej poprawności dyskursu o Zagładzie nie ma jednak mocy przesłonięcia osobliwego wrażenia, jakie wywołuje „normalność", którą jest przejęcie mienia eksterminowanych. Dyskurs tej „normalności”, jakkolwiek nie jest eksponowany, toczył się (i toczy) nader żywo. Chciałabym przedstawić jego podstawowe tropy, pojawiające się od oficjalnych głosów z lat okupacji do współczesności.

\section{Zadowolenie z „rozwiązania kwestii żydowskiej"}

Wątek polskiej „wewnętrznej” reakcji na Zagładę był długo tabuizowany: gubił się gdzieś między oficjalnym milczeniem i nie mniej oficjalnym anektowaniem ofiar do kategorii „ofiar polskich”. Pod tym oficjalnym milczeniem, na zmianę z zacieraniem specyfikacji, musiało się toczyć jakieś podziemne życie pamięci i myśli. Niebadane, więc pomijalne; pomijalne, a zatem bezpieczne. Wylewało się sporadycznie jakąś wieczorną przyśpiewką, że Oj dydy, oj dydy, oj wyzdychaty Żydy.... ${ }^{3}$.Taką ekspresję łatwo zbagatelizować: A tam, pijacy, popili i głupoty śpiewaja; nie jest źle mieć takich dyżurnych pijaków, podobnie jak nie szkodzi mieć dyżurny margines i patologię, które zdewastują resztki kirkutu lub pomalują na murach sześcioramienne gwiazdy na szubienicach. Wątpliwe jednak, czy to imaginarium jest wytworem pijaków i marginesu. Wątpliwości takie znajdują trojaką podstawę:

- w wiedzy o przedwojennym antysemityzmie w Polsce;

- w znajomości źródeł z okresu okupacji, odnoszących się do Zagłady i jej skutków;

- w głosach, które pierwsze przełamywały tabu oficjalnego pomieszania odmowy pamięci i złej pamięci.

Stwierdzenie Joanny Tokarskiej-Bakir, że „tzw. ciemni ludzie nie wytwarzają tych treści, oni po prostu przyswajają i powielają treści wytworzone przez elity" "zwięźle przedstawia jedno z głównych źródeł zjawiska, aż nadto

pod okupacją niemieckq i we wczesnych latach powojennych 1939-1950, Wydawnictwo Stowarzyszenia Centrum Badań nad Zagładą Żydów, Warszawa 2014, s. 184-194.

4 J. Tokarska-Bakir Rozum w Polsce wysiada, rozmowa z Joanną Tokarską-Bakir, "Przegląd” 18-24.08.2014 $\mathrm{nr} 34$, s. 7-9. 
chętnie przedstawianego jako antysemityzm ludowy. Koresponduje ono z moim spostrzeżeniem o znacznej dogodności posiadania marginesu społecznego, któremu w potrzebie można przypisać poglądy i zachowania formalnie nieakceptowane w oficjalnym dyskursie; ale jednak wśród rozlicznych działań marginesu społecznego nie znajduje się pisanie broszur ani redagowanie ulotek. Jeśli więc margines kolportuje pewne treści lub - co częstsze - kształtuje wedle nich swoje zachowanie, to nie znaczy, że je wytworzył5. Tokarska-Bakir nie pozostawia złudzeń: „To rzecz, o której w naukach społecznych mówi się od niedawna, ale w Polsce nie mówi się wcale. [...] powielanie najgorszych stereotypów społecznych wcale nie wiąże się w takim stopniu, jak sądzono, z działalnością tzw. ciemnego ludu, że odpowiedzialne są właśnie elity, które te stereotypy legitymizują".

Osobliwemu zatarciu ulega przy tej „diagnozie” oczywistość, że ów ciemny lud bynajmniej nie był społecznością autonomiczną. Wręcz przeciwnie bardzo długo podlegał rygorystycznemu nadzorowi. Nader liczne przekonania ludowe mają swoje korzenie w naukach, jakie lud pobierał oraz musiał przyswoić 7 . Łatwość narracji o jakimś wydarzeniu traumatycznym - w rodzaju pogromu czy „zdawania” ukrywających się Żydów - prowadzonej z użyciem kliszy sfanatyzowanego motłochu (który podpalał i linczował) okazuje się złudna. Do ujawnienia jej iluzoryczności wystarczą dwa proste pytania: 1. Kto, jak i dlaczego ten motłoch fanatyzował? 2. Czy przemiana ludu w motłoch jest zabiegiem tylko retorycznym?

Nie wynika z tego bynajmniej, że antysemityzm ludowy nie istnieje - wynika tylko tyle, że nie w jego obrębie powstała osnowa „racjonalnej” legitymizacji takiej postawy oraz właściwych jej praktyk. Warto zdać sobie sprawę z tego, ze w latach 1920-1939 prowadzono bardzo specyficzną i dość wszechstronną akcję oświecania ludu. Sporo uwagi poświęciła jej Alina Cała ${ }^{8}$. Rozważania Całej są dość niespójne: najpierw starannie rozróżnia antyjudaizm od antysemityzmu, po czym - omawiając antysemityzm, raz po raz wskazuje na wątki antyjudaistyczne; wszelako bez głębszej refleksji nad tym, co właściwie zostałoby z antysemityzmu, pozbawionego twardych

5 R. Kolarzowa Pani Dulska Polskę zbawi, w: A. Jamroziakowa Rewizje, kontynuacje?, Humaniora, Poznań 1996, s. 136.

6 J. Tokarska-Bakir Rozum w Polsce wysiada, „Przegląd” nr 34, 2014.

7 J. Tokarska-Bakir Legendy o krwi. Antropologia przesq̨du, W.A.B., Warszawa 2008.

8 A. Cała Żyd - wróg odwieczny? Antysemityzm w Polsce i jego źródła, Nisza - Żydowski Instytut Historyczny, Warszawa 2012, s. 87-92, 297-324, 383-413. 
schematów i stereotypów antyjudaistycznych. W interesującej nas kwestii przedstawia jednak czytelnie tę linię edukacyjną, opartą na katolickim antysemityzmie ${ }^{9}$. Warto zwrócić uwagę na pewną zbieżność chronologiczną: otóż wskazany przez Całą początek katolickiego antysemityzmu, który datuje na ostatnią dekadę XIX wieku, zbiega się z wielką debatą nad jednym z elementów zjawiska, określanego przez Hobsbawma jako wynaleziona tradycja, mianowicie nad kategorią narod $u^{10}$. Zwraca na to uwagę nawet Steinlauf, badacz skądinąd mało krytyczny"1. Ściśle, zbieżnością godną uwagi jest: a) silne dążenie do takiej redefinicji tej kategorii, która umożliwiłaby rozszerzenie jej na warstwy dotąd z niej wyłączone; b) konstruowanie nowej tożsamości dla tych warstw na fundamencie religijnym. Zwracam uwagę na nieprzypadkowość sformułowania „konstruowanie tożsamości” - nie można dłużej ignorować tego, że owa tożsamość była projektem (resp. konstruktem) wypracowanym poza środowiskami, które miały ją uwewnętrznić. Zrozumiałe też staje się uczynienie identyfikacji wyznaniowej fundamentem tego projektu: dla obdarzonych nim ludzi był to w końcu najbardziej rozpoznawalny element. Polak-katolik, zanim na dobre przyjął się jako twardy stereotyp, był tytułem gazety, reklamującej się jako najtańsze pismo codzienne. Gazeta ta, założona przez ks. Ignacego Kłopotowskiego, była przez niego samego określana (wraz z drugim tytułem) jako "pismo «wybitnie katolickie i antysemickie»"12. Pisma takie, adresowane do warstw niewykształconych, a transmitujące w uproszczonych (aż do karykatury) schematach narracji religijnej ideologię obozu narodowego, do 1939 roku miały najwyższe nakłady ${ }^{13}$. Daje się przy tym zauważyć pewna regularność: im bardziej proste schematy narracyjne, tym bardziej radykalna treść i tym wyższy nakład. Cała, powołując się na badania Modrasa, twierdzi: „Wraz z upolitycznieniem od początku XX w. Kościół coraz bardziej ulegał ideologii antysemityzmu, a nawet w dużej mierze przyczynił się do jej rozpropagowania w Polsce niepodległej, zwłaszcza

9 Tamże, s. 298. E. Hobsbawm Wprowadzenie. Wynajdywanie tradycji, w: E. Hobsbawm, T. Ranger (eds.) Wynaleziona tradycja, przeł. P. Godyń, F. Godyń, Wydawnictwo UJ, Kraków 2008, s. 10-21. M.C. Steinlauf Pamięć nieprzyswojona. Polska pamięć zagłady, przeł. A. Tomaszewska, Cyklady, Warszawa 2001, s. 25. A. Cała Żyd-wróg odwieczny?..., s. 308.

13 Tamże, s. 398-399. 
na prowincji. Stała się ona integralną częścią światopoglądu całej niemal wyższej hierarchii [...]"14. Mamy tu zarys odpowiedzi na pytanie o genezę sfanatyzowanego motłochu.

Antysemityzm ludowy istnieje; gdyby nie istniał, nie mobilizowałby tak mocno kilku pokoleń badaczy do zaprzeczania temu istnieniu i sentymentalizowania wzajemnych relacji. Jest to o tyle proste, że relacje te aż nadto często przedstawiane są w nazbyt wielkim uproszczeniu; tak jakby wieś była strukturą jednolitą, zamkniętą i autonomiczną, wolną od podwójnego nadzoru, który faktycznie występował aż do końca II RP.

W jaki sposób w procesie fanatyzacji dochodziło do harmonijnego połączenia antyjudaizmu i antysemityzmu, traktowanego jako integralny komponent projektu zwanego tożsamością narodową tych warstw, którym należało ją zaszczepićn ${ }^{15}$, opowiedział Tadeusz Markiel.

W okresie świąt bożonarodzeniowych domy odwiedzali kolędnicy z szopką. [...] Wśród nich zgarbiony, pejsaty, karykaturalnie ubrany Judasz z pielgrzymim kosturem i workiem na pieniądze u pasa - wiadomo, Żyd. Wtenczas przedobra ciocia Stasia wysunęła z miotły witkę brzozową i podając mi, siedmiolatkowi wówczas, powiedziała z uśmiechem: „Bij tym Żyda po garbie na plecach, będziesz miał zasługę przed Panem Jezusem". [...] bałem się, bo jakże to tak, bić dorosłego, który ma kij w ręku. Ciocia [...] dalej zachęcała: „No idź, bij, nic ci nie zrobi”. Odważyłem się w końcu uderzyć i o dziwo, Żyd się nie rozzłościł, nie zdzielił mnie kijem, bo Żydom mniej wolno. [...] Przyzwolenie na poniżanie Żydów szło z góry. Nikt nie mówił tego wprost, ale to się wiedziało. ${ }^{16}$

Ten wizerunek ludowy podlega wzbogaceniu przez nowe treści. Markiel potrafi wskazać ich nośniki.

w Gniewczynie na strychu u babci [...] znalazłem stary, z 1926 roku, katolicki miesięcznik (prawdopodobnie „Rodzina Polska”, brak kilkunastu

Tamże, s. 385; R. Modras Kościół Katolicki i antysemityzm w Polsce w latach 1933-39, Homini, Kraków 2004, s. 53, 117-118.

R. Kolarzowa Zaklinanie Realnego, „Teksty Drugie” 2015 nr 1, s. 51-52. czerów, Wydawnictwo Stowarzyszenia Centrum Badań nad Zagładą Żydów, Warszawa 2011, s. 46-48. 
początkowych stron) księży pallotynów z Wadowic, który tylko w tytule był katolicki, a w treści - antysemicki, ostro antysemicki. ${ }^{17}$

Jego relacja dostarcza też wiedzy o stosowanych w prasie katolickiej, adresowanej do maluczkich, socjotechnikach: gdyby wywody, utrzymane w konwencji „dyskursywnej” miały się okazać za trudne, pozostawało wykorzystanie schematu znanej pieśni:

Boże, coś Polskę przez tak liczne wieki

Bronił od Szwedów, Turków i Tatarów,

Coś ją wyzwolił z niemieckiej opieki

I na proch starłeś kajzerów i carów,

Przed Twe ołtarze zanosim błaganie:

Polskę od żydów racz wyzwolić Panie!

[...]

Żyd nasze miasta i wsie zawojował,

Handel i przemysł zabrał w swoje ręce,

Nawet uczelnie wyższe opanował

I kraj pogrążył w ubóstwie, w udręce;

Przed twe ołtarze...

[...]

Polska chce zrzucić te ohydne pęta,

chce być naprawdę wolną, narodową,

Przed Twe ołtarze... ${ }^{\mathbf{1}}$

Tak tworzył się klimat, który autor wspomnień zasadnie podsumowuje „Takim nauczaniem Kościół odczłowieczał polskich Żydów i wydawał ich w ręce hołoty! [...] Czy słowa pogardy i nienawiści [...] nie rozpaliły ognia w piecach Holokaustu?"19. Pytanie Markiela jest retoryczne tylko do chwili, gdy skonfrontuje się je z którąś z tuż przedwojennych wypowiedzi, pomieszczonych na łamach wysokonakładowych tytułów religijnych. Choćby ze słowami jednego z prominentnych duchownych, Stanisława Trzeciaka, który w 1939 roku na łamach „Małego Dziennika” rozwodził się nad opatrznościowym

\footnotetext{
17 Tamże, s. 54 .

18 Tamże.

19 Tamże, s. 55.
} 
posłannictwem Hitlera, dla którego wzorców upatrywał wśród wielkich papieży i świętych ${ }^{20}$. Reakcji ze strony katolickich intelektualistów na ten klimat właściwie nie było. Ani w Polsce, ani w Europie. Najbardziej zdecydowany głos Maritaina bliższy był pobłażliwego napominania niż zdecydowanej krytyki²1.

Lepiej wiadomo, dlaczego Jan Błoński konkludował: „Kiedy czyta się to, co o Żydach wypisywano przed wojną, kiedy się odkrywa, ile było w polskim społeczeństwie nienawiści - można się nieraz dziwić, że za słowami nie poszły czyny. Ale nie poszły (albo szły rzadko). Bóg tę rękę zatrzymał. Tak, Bóg, bo jeśli nie wzięliśmy udziału w tej zbrodni, to dlatego, że byliśmy jeszcze trochę chrześcijanami [...]"22. I nawet nietrudno jest domniemywać, dlaczego ten tekst, tak koncyliacyjny ${ }^{\mathbf{2 3}}$, wywołał bardzo gwałtowne reakcje - łącznie z nazywaniem „Tygodnika Powszechnego” - Żydownikiem Powszechnym.

Po relacjach, co w istocie było sednem ludowych żartów z żydowskich sąsiadów i że żarty te mogły kończyć się (i nieraz kończyły) tak, jak skończyło się w Kańczudze „wieszanie Judasza” w 1946 roku, powrót do narracji sielankowej wydaje się nie tyle mało możliwy, ile skazany na bardziej ograniczoną wiarygodność. Jakie są skutki odejścia od tego sentymentalizowania, dowodnie przekonaliśmy się przy sposobności publikacji prac J.T. Grossa i tych autorów, którzy zdecydowali się sielankową narrację po prostu porzucić lub przynajmniej częściowo zdekonstruować.

Podtrzymuję hipotezę, że opresja, jakiej doświadczali Żydzi w wiejskich społecznościach, mogła być: a) formą odreagowania opresji poddaństwa; b) przeniesioną formą odwetu ${ }^{24}$. Wstępnie na rzecz tej hipotezy przemawia obsesyjny wątek „tropienia żydowskości” (nie bez powodu eksploatowany przez ugrupowania populistyczne); lud inkorporuje to, co imaginuje sobie jako pożądanie (zakazanego) Innego, i czyni z tej trankrypcji pożądania własny

20 A. Cała Żyd-wróg odwieczny?..., s. 402.

B. Wasserstein W przededniu. Żydzi w Europie przed drugq̨ wojnq światowq̨, przeł. W. Jeżewski, Magnum, Warszawa 2012.

J. Błoński Biedni Polacy patrzą na getto, "Tygodnik Powszechny” $1987 \mathrm{nr} 2$.

Dodać trzeba, że koncyliacyjne nastawienie Jana Błońskiego nie wytrzymuje konfrontacji z ustaleniami badaczy Zagłady. Za słowami jednak poszły czyny. Takie, jak opisane przez J. Grabowskiego (Judenjagdt. Polowanie na Żydów, Warszawa 2004) czy J.T. Grossa (Sąsiedzi. Historia zagłady żydowskiego miasteczka, Warszawa 2000). Te dwie monografie są szczególnie istotne, ponieważ dotyczą wydarzeń z różnych regionów Polski - ukazują więc, jak bardzo cel ujednolicenia narodu został, w tym jednym punkcie, osiągnięty.

R. Kolarzowa Zaklinanie Realnego..., s. 48-59. 
fantazmat. Niemożliwy do skonstruowania w formie bezpośrednio odnoszącej się do nas - choć i takie elementy się pojawiają (choćby odwieczność trwania w jednym miejscu czy też odwieczność ojcowizny). Ten ostatni element dobrze ilustruje "czystość” fantazmatu - imaginacja o odwieczności ojcowizny uprzytamnia, jak dalece z pamięci została wymazana niedawność nabycia chłopskiego prawa własności ziemi). Możliwy jednak staje się w formie przeniesionej, eksponując: a) pożądanie władzy; b) pożądanie użycia władzy do „szkodzenia”.

Być może podobną ewolucję przeszła wyparta trauma, związana z nagim $\dot{z} y$ ciem $^{25} \mathrm{i}$ jego eksploatacją - i ujawniła się w polowaniach na Żydów jako zwierciadlane odbicie pożądania władzy nad życiem. Tej samej, której podleganie zostało „unieważnione” przez (intencjonalnie inkluzywną) narrację „tożsamości narodowej”, połączonej z obietnicą uznania w zamian za „odnalezienie się" w tej narracji, choćby mimetyczne. Na rzecz takiej możliwości interpretacyjnej zdają się przemawiać zarówno badania problematyki Zagłady, prowadzone „po Grossie”, jak i badania nad mentalnymi swoistościami polskiej transformacji ustrojowej. O obecności wątku pożądania władzy nad życiem świadczy przytoczony wcześniej fragment wspomnień T. Markiela: scena zachęcania dziecka, a więc istoty w strukturze wiejskiej rodziny znajdującej się niewiele wyżej od gospodarskiego inwentarza, do bicia dorosłego Żyda nie pozostawia wielkich wątpliwości: ten, który może być bity przez najniżej postawionego w hierarchii, znajduje się na samym dnie. Tłumaczenie, że to bicie jest symboliczne, należy pozostawić tam, gdzie jest jego miejsce - w narracjach sielankowych, zapoznających znaczenie przemocy symbolicznej. Raczej pożądane jest zreflektowanie skutków takiej pedagogiki, zwłaszcza gdy jest ona wzmocniona pozytywną motywacją religijną. Skutki tej pedagogiki ujawniły się również po wojnie ${ }^{26}$.

Na rzecz tej hipotezy przemawiają również inne akty przemocy, wielokrotnie opisywane, acz niekoniecznie reflektowane. Nie trzeba było pogromu wystarczyło zniszczenie odzieży, zbezczeszczenie domu modlitwy, zakłócenie pogrzebu (ze znieważeniem zwłok włącznie) czy podpalenie chrustu, który ubogi Żyd niósł na plecach.

25 Kategorie nagiego życia oraz (dalej w tekście) biowładzy stosuję $w$ takim znaczeniu, jakie zaproponował je G. Agamben, w Homo sacer. Suwerenna władza i nagie życie, przeł. M. Salwa, Warszawa 2008. 
Nie do przecenienia jest tu trop podany przez A. Ledera, zwłaszcza zaproponowane przez niego powiązanie Lacanowskiej kategorii transpasywności z uczestnictwem w przemocy ${ }^{27}$ :

najważniejsze były „pragnienia” biorące na cel z jednej strony Żydów, z drugiej - Polskę „pańską”. W ogromnej mierze i dla wielkich odłamów społeczeństwa oba te pragnienia nasycone były niechęcią, bardzo jednak różniły się między sobą w ekspresji. O ile wrogość wobec Żydów i pragnienie, „by znikli”, już dawno przed wojną znalazły znakomity wyraz w ideologii narodowej demokracji i nauczaniu Kościoła katolickiego, o tyle wielowiekowa niechęć wobec szlachecko-urzędniczych elit była o wiele bardziej skryta. [... ] Wskutek tego wobec Żydów można było zupełnie otwarcie snuć okrutne czy pogardliwe fantazje, a nawet podejmować agresywne działania, zaś wobec ówczesnych, wywodzących się $\mathrm{z}$ dworu elit narodowych - nie. ${ }^{28}$

Nie do końca zgodzę się z Lederem, że „brakowało języka, który usankcjonowałby mściwe fantazje „maluczkich” wobec niedawnych absolutnych hegemonów. Taki język był - ale przez narrację „wynalezionej tradycji narodowej” został p r z e ki e r o w a ny. Znakomita część ideologii narodowej demokracji jest wysiłkiem na to właśnie obliczonym, aby ustanowić „bezpieczny obiekt” nienawiści, która eksplodowała w 1846 roku i bliska była ponownej eksplozji w niewiele ponad dekadę później. Ta eksplozja, niezbyt odlegle poprzedzająca debatę o niezbędności rekonstrukcji tożsamości narodowej, zapisała się w pamięci warstwy dominującej dostatecznie wyraziście, aby skłonić do wypracowania strategii przekierowania możliwej ponownej eksplozji na obiekt „zewnętrzny"29. Elementem tej strategii przekierowania było wzmacniane przyzwolenie na fizyczne dręczenie Żydów; być może tu właśnie tkwi klucz do zrozumienia zarówno nasilenia się akcji pogromowych od schyłku XIX wieku do końca międzywojnia, jak i ożywienia legend o krwi. Tę strategię Markiel dobrze rozpoznaje jako formę manipulacji, dzięki której „można się

27 A. Leder Prześniona rewolucja. Ćwiczenia z logiki historycznej, Wydawnictwo Krytyki Politycznej, Warszawa 2014, s. 20-24. Por. także analizę znaczenia "załatwiania problemów społecznych cudzymi rękami" dla zbiorowej tożsamości. A. Kubiak Rzeczy mniejsze. Dysformia i fiasko: semi-peryferyjne formy kultury, Wydawnictwo URz, Rzeszów 2015, s. 158-160.

Tamże, s. 34 .

A. Kubiak Rzeczy mniejsze..., s. 132-134. 
było na nich wyżywać, odreagować stres, bezkarnie wyśmiewać [...]"30.Takie odreagowanie było niezbędne, ponieważ napięcia społeczne były na wsi bardzo silne - i bynajmniej nie Żydzi byli ich źródłem. Wielka fala strajków chłopskich, która przeszła przez Małopolskę w latach 30., nie była wywołana obecnością żydowskich sąsiadów, ale przede wszystkim głodem ziemi; ten zaś był skutkiem systemu gospodarczego, preferującego wielką własność ziemską oraz mniej niż skromnymi efektami uchwalonej w 1925 roku reformy rolnej. Strajki te były brutalnie pacyfikowane przez policję państwową; ponadto na wsi „ludzie pamiętali [...] krzywdy ze strony urzędników i sądów, krzywdy ze strony ekonomów i polowych w folwarkach wschodniej Polski, gdzie małorolni harowali od wiosny za marny grosz i wracali - jak mój ojciec - na jesieni

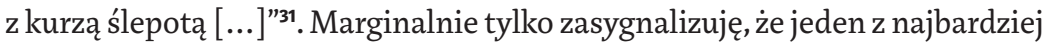
eksploatowanych tropów antysemickich, rozpijanie narodu, jest bodaj jedną z najstarszych form odwrócenia uwagi od rzeczywistych posiadaczy monopolu alkoholowego - zarówno w jego postaci feudalnej i postfeudalnej (prawo propinacji), jak i nowożytnej (monopol państwowy). Złorzeczenie na rozpijanie narodu przez Żydów było wypowiedzią „w dobrym tonie” - złorzeczenie na monopol dworski lub państwowy - nie. Aby wypowiedź „niewłaściwą” zmienić na tę „, dobrym tonie", nie trzeba było zmiany języka - wystarczyła zmiana podmiotu - obiektu złorzeczenia.

Jak dalece skuteczne było to przekierowanie, ujawniają zarówno badania B. Engelking, J. Tokarskiej-Bakir, J. Grabowskiego czy najnowszy tom pod redakcją J. Grabowskiego i D. Libionki, jak i dokumenty nieczęste - wspomnienia z polskiej strony, dotyczące lokalnych wydarzeń okupacyjnych, w rodzaju przywoływanej tu pracy T. Markiela i A. Skibińskiej czy starszych relacji, zwłaszcza Kazimierza Wyki Życie na niby. Rozważania Wyki na długo zostały zeskamotowane - był to jeden z powodów, dla których znacznie mniej dosadny, bo skupiony przede wszystkim na antropologicznej analizie wiersza, tekst Błońskiego wywołał tak wielki opór, w najdosłowniej psychoanalitycznym sensie. Nie sposób w materiałach źródłowych, analizowanych przez wymienionych badaczy, oddzielić pożądania wtasności od pożąania życia właściciela. Rozumiejąc potrzebę zachowania ostrożności interpretacji, trzeba jednak zauważyć pewną pokusę: uznanie priorytetu chciwości, zwłaszcza chciwości biedaków, może stanowić pewną, najczęściej domyślną, okoliczność łagodzącą. Śmierć, zadana dla uzyskania jakiejś korzyści, takiej zwłaszcza,

T. Markiel, A. Skibińska „Jakie to ma znaczenie, czy zrobili to z chciwości?”..., s. 48. 
której w innych okolicznościach trudno byłoby się spodziewać, wydaje się jeszcze jakoś racjonalna. Tę racjonalność podważa pytanie Markiela - jakie, gdy mowa o zadawaniu śmierci, może mieć znaczenie, czy uczyniono to z chciwości? Racjonalności tej nie można utrzymać, zważywszy powracającą w licznych relacjach skromność owych korzyści - czy to będących zapłatą władz okupacyjnych za „zdanie” Żyda, czy to będących tego Żyda własnością. Niewspółmierność owych korzyści (kilka kilogramów cukru, para butów czy chustka ${ }^{32}$ z wydaniem na śmierć lub osobiście dokonanym zabójstwem rodzi domniemanie, że ta korzyść de facto ma charakter symboliczny - ruchomości, należące do przedmiotów codziennego użytku, odebrane zazwyczaj niezbyt zamożnym lub wręcz ubogim Żydom nie są wartościowe „same w sobie”, ale mają wartość trofeum. Taki trop lepiej pozwala zrozumieć jedno ze wspomnień A. Bieńkowskiego:

młoda, piękna Żydówka ucieka z dwójką małych dzieci z transportu pod Białobrzegami. Znali ją, wszyscy to podkreślali. Idzie do lasu, a za nią chłopaki z kijami, w jej wieku. Żydówka mogła mieć dwadzieścia trzy lata, jedno dziecko cztery lata, drugie trzy. No i dwudziestu chłopaków zatłukło ich kijami, dla samej przyjemności, nikt z tego nic nie mi ał. ${ }^{33}$ [wyróż. - R.K.]

Zwraca uwagę dwuznaczność tego zestawienia zattuc dla samej przyjemności i nikt z tego nic nie miat. Odsłania ona inny niż czysto materialny wymiar korzyści i otwiera perspektywę na świat biowładzy, w którym obiekt dozwolony może również substytuować obiekt zakazany. Ten wątek biowładzy przewija się bardzo wyraźnie u Grabowskiego ${ }^{34}$ i Engelking. Na odrębne studium zasługuje język relacji, dotyczących polowań na Żydów czy też obław - wyklucza on obiekty tych łowów ze świata ludzkiego. Zarazem ustanawia polujacych w pozycji „mocy przeznaczenia” - czynnika determinującego granicę życia;

B. Engelking lest taki piękny, słoneczny dzień... Losy Żydów szukających ratunku na wsi polskiej 1942-1945, Wyd. Stowarzyszenie Centrum Badań nad Zagładą Żydów, Warszawa 2011, s. 111-114.

J.T. Gross, I. Grudzińska-Gross Złote żniwa. Rzecz o tym, co się działo na obrzeżach zagładyżydów, Znak, Kraków 2011, s. 105. Przytoczony fragment ujawnia opór prze uznaniem korzyści, jaką jest (opisane przez Agambena) poczucie bezwzględnej władzy nad życiem. Por. G. Agamben, Homo sacer..., s. 48 in.).

Por. relacje, zawarte w Judenjagdt. Polowanie.... Swoiste studium języka dehumanizacji oraz szantażu Grabowski przedstawił w monografii "/a tego Żyda znam". Szantażowanie Żydów w Warszawie 1939 -1943, Warszawa 2004. 
bo tylko z takiej pozycji możliwe jest powiedzenie dosyć żyłeś. Na ile ta pozycja była uświadamiana, wskazuje fraza my nic od was nie chcemy, tylko życie wasze ${ }^{35}$.

Nie znaczy to, że perspektywa materialnych korzyści z zagłady Żydów uchodziła uwagi czy była traktowana jako nieistotna. Wręcz przeciwnie, oczekiwania były mocno nadmiarowe. Wszystkie dotychczasowe badania nie pozostawiają wątpliwości, że kondycja materialna większości Żydów polskich, zamieszkujących w sztetlach i na wsiach, była porównywalna ze stanem posiadania ich polskich sąsiadów. Jednak realne ubóstwo tej społeczności nie miało wpływu na stereotyp bogatego Żyda. Ten stereotyp zaś znajdował uszczegółowienie w imaginacji, że Żyd to złoto. Toteż w materiałach dotyczących polowań znaczne miejsce zajmują relacje poświęcone wymuszaniu na Żydach informacji o miejscach ukrycia złota i kosztowności. W ich braku liczyło się dosłownie wszystko, także miejsca ukrycia wartościowszej odzieży czy sprzętów domowych. W proporcji do zorganizowanej nazistowskiej machiny aryzacji mienia żydowskiego ${ }^{36}$ to są sprawy bardzo drobne; i tym bardziej dojmują jako świadectwo traktowania Żydów w kategorii nagiego życia - mniej znaczącego od najskromniejszego zasobu materialnego, którym można było zawładnąć. Tam, gdzie wiadomo było, że biurokratyczna machina okupacyjna dociera sporadycznie, można było podejmować działania indywidualne. W relacji Markiela porusza historia dwóch biedaków, ojca i syna, których „być może obciążało [...] posiadanie domu, biednego, ale jednak domu, który mógłby się miejscowym przydać"37. Ukrywali się tak, że

Nawet stu niemieckich policjantów nie potrafiłoby odnaleźć tej kryjówki. Musiał ktoś z miejscowych doprowadzić ich w ten ślepy zakątek wsi i wskazać dokładnie to miejsce. [...] Mieszkającemu w pobliżu sołtysowi Niemcy polecili zakopać martwe ciała [...] na niepoświęconej ziemi, gdzie wieśniacy zakopują martwe zwierzęta. [...] Sołtysowi i jego pomocnikom nie przyszło nawet na myśl, aby [...] przenieść później, po cichu, ludzkie przecież zwłoki na miejsce zmarłych i oznaczyć groby. Nie zapomnieli tylko obszukać ich kieszeni i udeptać równo ziemię [...] $\mathrm{Na}$

B. Engelking Jest taki piękny, słoneczny dzień..., s. 184-194, 217 i n.

J. Grabowki Zarząd Powierniczy i nieruchomości żydowskie w Generalnym Gubernatorstwie. „Co można skonfiskować? W zasadzie wszystko", w: J. Grabowski, D. Libionka (red.) Klucze i kasa. O mieniużydowskim w Polsce pod okupacją niemiecką i we wczesnych latach powojennych 1939-1950, Wydawnictwo Stowarzyszenia Centrum Badań nad Zagładą Żydów, Warszawa 2014, s. 73-112. 
ich posesji sąsiad Stefan Ch. postawił kapliczkę, aby „wygnać diabła” po Żydach i sobie zaklepać prawo do schedy po dwóch zamordowanych nędzarzach [...].38 [wyróż. - R.K.]

To ważna relacja, kondensująca kwestię sąsiedztwa, ugruntowanego antysemityzmu, w którym wątki ekonomiczny (przydatność biednego obejścia) i religijny („wyganianie diabta” po Żydach) nie są możliwe do odseparowania, oraz wiedzę o tym, że władza okupacyjna bynajmniej nie jest wszechwładna i ani sama nie wytropi każdej żydowskiej kryjówki, ani nie dorachuje się każdej żydowskiej chałupy.

To zredukowanie żydowskiego istnienia do nagiego życia, tu finalnie poświadczone pogrzebaniem zwłok na cmentarzysku zwierząt, wzmacniało, jak się zdaje, zarówno marginalizację takich wydarzeń, jak i uwewnętrznienie przekonania o prawie do sukcesji po eksterminowanych. Śmierć Żydów, wyłączonych z ludzkiej wspólnoty, stawała się zdarzeniem równie powszednim, jak śmierć zwierzęcia gospodarskiego. Albo i czymś jeszcze mniejszej wagi. Wymierne zaś dobro nie mogło się marnować. Wyróżniona ostatnia fraza często przewija się w dyskusjach nad problematyką obrzeży Zagłady; częstotliwość jej użycia wzrasta, gdy pojawiają się w tej debacie wątki ekonomiczne. Ustalił się schemat takich debat, szczególnie wyrazisty w przestrzeni wirtualnej: najpierw podnosi się nieproporcjonalność korzyści polskich w zestawieniu z bilansem całego procesu aryzacji mienia żydowskiego, potem zaś wskazuje się na lichotę tego mienia, do którego dostęp pozostawiono ludności polskiej, a wreszcie „racjonalizuje” przejmowanie go tą właśnie frazą.

Po latach funkcjonowania pamięci o Zagładzie w swoistym obiegu wewnętrznym lokalnych społeczności ${ }^{39}$ nastąpiło wyraźne i jawne przemieszczenie pozycji podmiotowej: sukcesorzy postrzegający się jako ofiary (możliwych) roszczeń. Ma rację Gross, gdy odsyła do Tacyta, tłumacząc fenomen nienawiści do tych, których się skrzywdziło ${ }^{40}$. Szczegółowe relacje o takich przemieszczeniach znajdujemy w wywiadach przeprowadzonych przez

38 Tamże, s. 104-105.

39 J.T. Gross, I. Grudzińska-Gross Złote żniwa..., s. 125-134.

40 J.T. Gross Strach. Antysemityzm w Polsce tuż po wojnie. Historia moralnej zapaści, Kraków 2008, S. 298. 
zespół J.Tokarskiej-Bakir. Gdy mowa o powojennych zabójstwach ocalałych Żydów, powracają frazy wojowali o swoje, gdyby tak nie wojowali o swoje $e^{41}$.

Tokarska-Bakir wróciła do tego wątku w Okrzykach pogromowych:

Front posunął się dalej... i skądś się właśnie ci Żydzi wzięli, kilka rodzin, nawet z Sandomierskiej ulicy, skądś się wzięli. No, i zaczęli bardzo wojować, tak!! Że to ich! Że my teraz pokażemy, co my potrafimy, ta. Pamiętam, że w ciąży taka Żydówka była, i też ją zabili [...] No, nie trzeba było za bardzo tak, to może by przeżyli. [...] w każdym razie kilka rodzin zostało, gdzieś schowani byli, ale przyszli na śmi ało, jak już Niemcy poszli [...] ...w wrócili na swoje, bo Niemców nie ma, no bo to tak a ze ms ta była.Zemsta, czy ja wiem co? [wyróż. - R.K.]

Określenie „zemsta” powraca tu najpierw w kontekście domniemanych pretensji Żydów („zaczynają wojować”, „że to my teraz pokażemy, o potrafimy”), potem w kontekście pretensji do Żydów („może tam pretensje jakie mieli do nich?").W języku wywiadów sandomierskich klimontowską tragedię z wiosny 1945 roku [...] można by zatem opisać jako starcie dwóch dyskursów zemsty: (realnej) polskiej i (domniemanej) żydowskiej. Nie byłby to jednak opis obiektywny. [...] motywów zemsty nie znajdziemy w przytaczanych już relacjach żydowskich; dominuje w nich dyskurs krzywdy, żałoby i wycofania. Jedynie pole polskiego rozumienia rzeczywistości powojennej zorganizowane jest konsekwentnie przez słowo „zemsta".42

W relacji tej możemy prześledzić proces obsadzenia ocalonych z Zagłady w roli „odwiecznych wrogów” - samo ich pojawienie się może być zinterpretowane jako zemsta. Tym bardziej, gdy pojawili się na śmiało - ci, którzy byli nagim życiem, nad którym miało się władzę; i to po to, aby dopominać się o swoją własność. To upominanie się zostaje nazwane wojowaniem. Samo przeżycie jest aktem na złość, a zamiar odzyskania domu - aktem zemsty. Ofiarami nie są ci wojujący - ofiarami są ci, którzy ten dom zajęli.

Tokarska-Bakir już wcześniej nie zostawiła złudzeń, jaki miał być obowiązujący paradygmat załatwiania spraw mienia żydowskiego. „Żydów miało już nie być, więc mieli zachowywać się tak, jakby ich nie było. W rewanżu

41 J. Tokarska-Bakir Legendy o krwi...

42 J. Tokarska-Bakir Okrzyki pogromowe. Szkice z antropologii historycznej Polski 1939-1946, Czarne, Wołowiec 2012, s. 93-94. 
społeczność lokalna skłonna była przygotować dla nich jakiś kącik muzealny, pomnik, tablicę"43. Żydzi, jeśli byli, mieli akceptować ten stan rzeczy; i godzić się, że przejęte mienie będzie nazywane przez tych, którzy je przejęli i ich spadkobierców - dziedzictwem ${ }^{44}$. A ich pozycja wobec tego dziedzictwa zostanie określona prawami rezerwatu. Polscy właściciele poduszki pani Marx nie mają spokojnych snów - tym jednak, co najbardziej doskwiera, jest myśl, że jakieś wnuki Pani Marx mogą o tej poduszce przypomnieć.

\section{Abstract}

\section{Romana Kolarzowa}

RZESZÓW UNIVERSITY

Heavy Dreams on 'Mrs Marx's Pillow': The Hidden Euphoria of Postwar Succession in Poland

Kolarzowa examines the formation of the 'discourse of normality' around the Holocaust and its material consequences. She points to the relationship between anti-Semitism and the construction of a new national identity in Poland, as well as the ideological blurring of actual social structures. The intensive operation of 'enlightening the people' (19201939) is presented as an immediate source of positions regarding the Holocaust, as this operation was marked by aggressive nationalism, which was legitimized using religion. Kolarzowa suggests that the brutality and dehumanization that Jews experienced in rural communities could have been a form of abreaction, a discharge related to the oppression of serfdom and a transferred form of retaliation. The Jew then became a phantasm of the lord; violence towards Jews - an accessible object - became a substitute for violence towards social sovereigns - a forbidden object. As a consequence, notions were internalized about the right to succession: to inherit the property of those who were put to death and to transfer the subjective position in such a way that the people who took over the Jewish patrimony could view themselves as victims of (potential) claims.

\section{Keywords}

the Jewish question, Jewish property, displacement, abreaction, oppression

43 J. Tokarska-Bakir Legendy o krwi..., s. 558.

44 Problem ten został poruszony w polemice Konrada Matyjaszka z E. Lehrer. Zob. K. Matyjaszek Regulamin rezerwatu. O ksiq̨żce Jewish Poland Revisited Eriki Lehrer, "Studia Litteraria et Historica" 2015; http://doi.org/10.11649/slh.2015.007. 